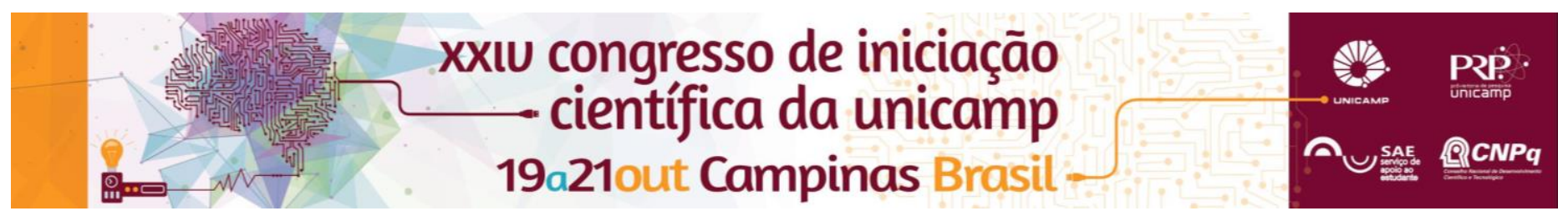

\title{
Argumentos silogísticos, entimemas e retórica nas artes liberais clássicas do Trivium
}

\author{
Giovanna Canovas Viana*, Heberson Lucas Soares de Barros*, Letícia Maria de Jesus Dias*, Mateus Augusto \\ Menezes Batista*, Fabio Maia Bertato (Orientador)
}

\begin{abstract}
Resumo
No projeto "Lógica e Interdisciplinaridade", vigente entre Agosto de 2015 e Julho de 2016, os livros mais abordados e trabalhados foram O Trivium: As Artes Liberais da Lógica, da Gramática e da Retórica, de Miriam Joseph, e a llíada, de Homero. Apenas com esses dois livros podem-se abordar muitos temas. No entanto, por conta de espaço, para ser apresentado ao congresso selecionamos três temas que foram notadamente discutidos ao longo do projeto, que são: Silogismo, Entimema (ambos no âmbito da Lógica do Trivium) e Retórica. Um silogismo é um argumento que conta com duas proposições (premissas), das quais é deduzida uma última, a conclusão; dessas duas premissas, uma chama-se maior e, outra, menor. Existem quatro espécies de proposição no que se refere ao tipo de afirmação ou negação e essas são abreviadas pelas cópulas simbólicas $\underline{\mathbf{A}}$, $\underline{\mathbf{E}}, \underline{\underline{I}}$ e $\underline{\mathrm{O}}$ : $\mathbf{A}$ (afirmativa universal), $\underline{\mathbf{E}}$ (negativa universal), I (afirmativa parcial) e o (negativa universal); por exemplo: "S a P", onde S é "Homem" e P é "mortal"; assim "S a P" significa "Todo homem é mortal". Isso considerado, são possíveis apenas 64 combinações dentre as proposições, dentre as quais apenas 19 são logicamente válidas, distribuídas nas quatro figuras do silogismo. Como método para verificação (e consequente exposição) da validade lógica dos silogismos utilizamos os Diagramas de Venn. Por sua vez, ainda dentro do estudo dos silogismos, vimos os chamados Entimemas, que também são compostos de duas premissas e a partir delas tiramos uma conclusão, porém no entimema uma proposição - mais frequentemente a premissa maior - está implícita e, por ter algo implícito, não é raro que um entimema seja tomado como verdadeiro quando na verdade é falso; em termos de definição, é um silogismo com uma premissa abreviada. Por fim, a Retórica foi estudada como a arte da persuasão, datada desde a Antiguidade. A persuasão (convencimento) é obtida por meio de três principais elementos da Retórica, que serão abordados em nossa apresentação; são eles o Ethos, o Páthos e o Logos. O Ethos é uma primeira parte do discurso e se refere às características do orador a fim de convencer as mentes dos ouvintes ou leitores pela sua credibilidade, mostrando, por exemplo, confiança em seu temperamento e reputação, competência, conhecimento do público, bom senso, honestidade etc.; o Pathos já é um segundo momento do discurso e opera um tipo de apelo emocional no público, de modo a propiciar um clima para a recepção daquilo que o emissor quer apresentar e convencer, o Logos. O Logos, por fim, é a parte do discurso que contém o conteúdo daquilo que o orador (autor, ou emissor) quer convencer seu público depois de tê-lo preparado; nele, usa-se da lógica e da força dos argumentos. Exemplificaremos esses três elementos da Retórica com trechos da llíada de Homero.
\end{abstract}

\section{Palavras-chave}

Artes Liberais; Lógica tradicional; Silogismo; Entimema; Retórica. 